Yits un supplements poor cultivation by basket. work on handicraft lines, with small but quick turnover, and by paper making, a process taking a year and making capital necessary. Paper mills rarely work all round the year for lack of bamboos, and they, like the land, are divided in inheritance. Investment in the poor land rarely pays, so profits from paper go elsewhere.

All in all, the lowly folk find advance almost blocked in every case and every direction unless one or two of them can become government officials and then use opportunities to enrich themselves and their families. One can but hope that efficient co-operative systems under schemes of public ownership may help these peasants. It is hoped that this interesting study may be made available in published form in England. before long.

H. T. Fleure.

\section{ECOLOGICAL PRINCIPLES IN FORESTRY PRACTICE}

$\mathrm{A}^{\mathrm{T}}$ $T$ the invitation of the British Ecological Society, members of the forestry associations of Great Britain met on July 2 to discuss with the Society problems arising from a recent article by Sir Roy Robinson in Forestry. Prof: A. G. Tansley, opening the session, argued that the hypotheses of the "silvicultural stream" and of "accelerated succession" are based on ecological theories of succession, mixed plantings of pioneers and successors comparing with natural "telescoped" succession. He indicated the mutual benefits of still closer co-operation between foresters and ecologists, especially in investigations of the effects of pioneers on successors and of the autecology of exotic conifers. He also pleaded for due consideration by the Forestry Commission of the needs of nature conservation, particularly in view of the envisaged expansion of the Commission's programme after the War.

Sir Roy Robinson welcomed fullest co-operation from ecologists, the more especially because afforestation policy must be based on sound ecological principles. He indicated, among other pressing problems, those of soil relations, mixed plantations, and regeneration by means other than clear felling and planting. Prof: H. G. Champion instanced, from India, the ecological effects of soils and climates in determining the status of timber trees and the nature of climax and pre-climax complexes. He also discussed the importance of factors operating at comparatively long; intervals, such as excessive drought and frost. Stressing the complexity of sylvicultural streams, he pointed out that afforestation may sometimes need to run counter to their currents. Dr. A. S. Watt stated the need for a dynamic conception of forest ecology. The pattern of the forest plantation must be determined by a variety of causes: microclimates, soils, relations between one plant and another, and the structure of the vegetation; the organic factors of the environment being no less important than the inorganic.

Discussion afterwards ranged widely over problems such as the status of afforestation programmes in national planning of land utilization and the construction of an ecological survey map of the British Isles; the function of shade bearers in controlling ground vegetation; the relative importance of surface vegetation and soil profile as a guide to planting ; the functions of leaf litter, and of mycor. rhiza and sub-shrub vegetation in regeneration; mixed planting and control of disease; the role of the smaller animals in the forest balance; and the need for preservation of samples of broad-leaved forest $(a)$ for ecological study and advice in future programmes, and $(b)$ as a part of the systematist's laboratory.

Sir Roy, replying to the discussion, reiterated his welcome of co-operation from ecologists, and stated that the Forestry Commission's ecological reserves would be re-established after the War, and that it is important to nominate now those woods desirable for such purposes, in view of the vast felling programme now in operation.

L. A. HaRvey.

\section{APPOINTMENTS VACANT}

Applications are invited for the following appointments on or before the dates mentioned

SPEECH TherapisT (part-time)-The Education Secretary, Town Hall, Reigate, Surrey (August 20).

LECTURER (TEMPORARY) IN CHEMISTRY - The Registrar, University College, Southampton (August 25).

Professor of Physiologr, a Senior Lecturer in ANATOMY, and A SENIOR LECTURER IN PHYSIOLOGY, in the University of Otago, Dunedin-The High Commissioner for New Zealand, 415 Strand, London, W.C.2 (August 31).

CHEMIST AND ASSAYRR on the establishment of the South African Mint, Pretoria-The Secretary, Office of the High Commissioner for the Union of South Africa, South Africa House, Trafalgar Square, London, W.C.2 (August 31).

Heads of the Departments of Physiology, Medicine, and SURGERY-The Bursar, Royal Veterinary College and Hospital, at The University, Reading (October 1).

CHAIR of NAVAL ARCHITECTURE-The Acting Secretary of University Court, The University, Glasgow (October 4).

Assistant To THE ADVISORY CHEMisT-The Secretary, SouthEastern Agricultural College, Wye, Ashford, Kent.

ASSISTANT (MALE OR FEMALE, preferably with a knowledge of ASSISTANT (MALE OR FEMALE, preferably with a knowledge of
Bacteriology and Chemistry) for Laboratory-The Pathologist, Cumberland Infirmary, Carlisle.

Teacher (MaN oR wOMaN) OF Mathematics, Mechanics and elfmentary ScIexce-The Principal, Erith Technical College, Belvedere, Kent.

\section{REPORTS and other PUBLICATIONS (not included in the monthly Books Supplement)}

\section{Great Britain and Ireland}

Annual Report of Gresham's School Natural History Society, 1943. Pp. ii + 32. (Newquay: Gresham's School.)

Curriculum and Examinations in Secondary Schools. Report of the Committee of the Secondary School Examinations Council appointed by the President of the Board of Education in 1941. Pp.
ix +151 . (London : H.M. Stationery Offlce.) 18. $6 d$. net.

Medical Research Council. War Memorandum No. 10: The Medical Use of Sulphonamides. Pp. 46. (London: H.M. Stationery Office.) Use of Sulphonamides. Pp. 46. (London: H.M. Stationery Office.
[287 $9 d$. net.
Association of University Professors of Allied Countries in Great Britain : Educational Conference, May 11, 1943. The Function of University in a Modern Community. Pp. vi +57. (Oxford : Basil
[297 Blackwell.) 18.
Geological Survey of Great Britain : Scotland. Wartime Pamphlet No. 30: Sands and Gravels of Scotland, Quarter-inch Sheet 9: Elgin, Banff, Aberdeen. By Dr. J. G. C. Anderson. Pp. 27. (London Geological Survey and Museum.) is, $4 d$.

\section{Other Countries}

Indian Forest Leaflet. Utilisation No. 37 : How to Identify Timbers, Part 3: Timbers for Motor Lorry Bodies. By K. Ahmad Chowdhury. Pp. ii $+17-30.4$ annas; $6 d$. Utilisation No. 41: Studies hury. Pre on Adhesives, Part 5 : A Presives. By D. Narayanamurti and V. Formaldehyde Resin Adnesives. $;$. Utilisation (New Series), No Ranganathan. Pp. il murti, V. Ranganathan and Mohammed Ikram. Pp. ii + 22. 4 annas ; 6d. (Dehra Dun : Forest Research Institute.) [297 Indian Forest Records. Utilisation (New Series), Vol. 2, No. 10 : A Survey of the Seasonal Variation of the Moisture Content of Indian Woods. By M. A. Rehman. Pp. vi + 209-244+6 plates. 1.4 rupees; 28 . Utilisation (New Series), Vol. 3, No. 1 : Note on Timber Roof Trusses with Solid Wood Disc Dowell Joints. By V. D. Limaye. Pp. ii $+7+5$ plates. 6 annas; 9d. Utilisation (New Series), Vol. 3, No. 2: The Thermal Conductivity and other Properties of some Indigenous Materials. By Dr. D. Narayanamurti. Pp. $1 i+13+3$ plates. 6 annas;
9d. (Delhi : Manager of Publications.) 